\title{
Reaction of Wheat Genotypes to Soil Aluminum Differential Saturations
}

\author{
Antonio Costa ${ }^{*}$, Luís Alberto Cogrossi Campos and Carlos Roberto Riede \\ Instituto Agronômico do Paraná; C. P. 481; 86001-970; antcosta@pr.gov.br; Londrina - PR - Brasil
}

\begin{abstract}
Ten wheat (Triticum aestivum) genotypes were evaluated in microplots with aluminum saturation of 0, 15, 30 and 45\%, during 1994, in Londrina, Paraná, Brazil. The soil was a Distrofic Red Latosol (Typic Haplorthox), with 65\% saturation of aluminum, amended with dolomitic lime. Variables evaluated included grain yield and yield components: ears. $m^{-2}$, grains.ear ${ }^{-1}$ and the weight of 1000 grains. Genotypes differed in yield and yield components. Increasing aluminum saturation decreased yield, ears. $m^{-2}$ and grains.ear ${ }^{-1}$, but did not alter thousand kernel weight. The genotypes reacted differently in relation to the toxic soil aluminum. Anahuac and IAPAR 29 were aluminum sensitive; OCEPAR 16, Trigo BR 18, and Trigo BR 23 were moderately sensitive; IAPAR 6, IAPAR 53, and IAPAR 60 were moderately tolerant; while IAC 5-Maringá and Trigo BR 35 were tolerant.
\end{abstract}

Key words: Triticum aestivum, aluminum tolerance, aluminum soil saturation, yield components

\section{INTRODUCTION}

Wheat is cultivated in the State of Paraná in a large diversity of soil types, several of them presenting high acidity, high level of exchangeable aluminum (Al) and low bases saturation. These characteristics contribute to high Al saturation, which restricts the subsoil root development, reducing the normal water and nutrients uptake by the wheat plants (Riede and Campos, 1988; Uexküll and Mutert, 1995). The use of lime and the neutralization of exchangeable $\mathrm{Al}$ in the subsoil are practices which present agronomic and/or economic difficulties to be executed, restricting a generalized utilization (Quaggio, 2000). The occurrence of toxic Al is particularly important when associated to water stress. In the North of Paraná the occurrence of drought in the establishment of the crop growth it is frequent, while in the West such phenomenom occurs most frequently in the grain filling period (Caramori et al., 1991). Under these conditions the use of Al sensitive cultivars seriously reduce the wheat yield potential (Okuyama and Costa, 1990). The use of Al tolerant wheat cultivars is a complementary solution to achieve high and stable yields of wheat when cultivated in acid soils of Paraná State. Genetic variability for tolerance to toxic Al exists among different species of plants and among cultivars of the same species which has allowed the selection of tolerant and productive genotypes, for the soil acidity environments (Foy and Brower, 1964; Carver and Ownky, 1995; Baligar and Fageria, 1996; Camargo et al., 1999). Tolerance to Al toxicity is one of criterion for wheat cultivar recommendation in Paraná. The index used for the recommendation of cultivars is the $\mathrm{Al}$ saturation (\%) of the soil to a depth of 60

\footnotetext{
* Author for correspondence
} 
cm (Muzilli et al., 1978; IAPAR, 2000). The present work was done to determine the degree of tolerance of wheat cultivars at different levels of $\mathrm{Al}$ saturation in the soil.

\section{MATERIAL AND METHODS}

The experiment was conducted during 1994, in microplots containing a Typic Haplorthox (latossolo roxo), collected at the Experiment Station of IAPAR, in Londrina, PR. The results of the original soil analysis indicated the values of: $\mathrm{pH} 3.6$ in $\mathrm{CaCl}_{2} 0.01 \mathrm{M}(1: 2.5) ; \mathrm{Al}^{3+} 25.5 \mathrm{mmol}(+) \mathrm{dm}^{-3}$; $\mathrm{H}^{+}+\mathrm{Al}^{3+} 121.3 \mathrm{mmol}(+) \mathrm{dm}^{-3} ; \mathrm{Ca}^{2+} 3.3 \mathrm{mmol}(+)$ $\mathrm{dm}^{-3} ; \mathrm{Mg}^{2+} 2.5 \mathrm{mmol}(+) \mathrm{dm}^{-3} ; \mathrm{K}^{+} 0.17 \mathrm{mmol}(+) \mathrm{dm}^{-}$ 3. CEC $128.8 \mathrm{mmol}(+) \mathrm{dm}^{-3}$ and $5.82 \%$ and $65.27 \%$ for bases and $\mathrm{Al}$ saturations, respectively. The experiment was set in randomized blocks, with subplots and three replications. The amount of lime used in the plots was determined by the incubation of soil with dolomitic lime, for 45 days, and defined by the regression equation $\mathrm{Y}=67.52-63.55 \mathrm{X}+$ $15.11 \mathrm{X}^{2}$, where $(\mathrm{Y})$ represents the estimated $\mathrm{Al}$ saturation as a function of the lime levels $(\mathrm{X})$. To reach the $\mathrm{Al}$ saturations of $45,30,15$, and $0 \%$, doses of $0.39 ; 0.71 ; 1.33$ and $2.75 \mathrm{~g}$ of lime $1^{-1}$ of soil were applied. The dolomitic lime used contained $202.02 \mathrm{~g} \mathrm{~kg}^{-1}$ of $\mathrm{Ca}^{2+}, 121.78 \mathrm{~g} \mathrm{~kg}^{-1}$ of $\mathrm{Mg}^{2+}$, and effective neutralization power of 20.08 $\operatorname{mol}(+) \mathrm{kg}^{-1}$. The subplots consisted of 10 wheat cultivars, sowed in two rows of $1 \mathrm{~m}$ per cultivar, spaced in $0.20 \mathrm{~m}$ and each microplot had $0.40 \mathrm{~m}^{2}$. The evaluated genotypes were: 'Trigo BR 23', 'IAPAR 29', 'IAPAR 60', 'OCEPAR 16', 'Trigo BR 35', 'IAPAR 6', 'IAPAR 53', 'Trigo BR 18', 'IAC 5Maringá', and 'Anahuac'. Plots were irrigated when necessary. Grain yield and yield components, number of heads. $\mathrm{m}^{-2}$, number of kernels per head, and thousand kernel weight were determined. The results were submitted to an analysis of variance, being the means of qualitative parameters compared by grouping of Scott-Knott to $5 \%$ of probability. The quantitative parameters were adjusted by exponential, quadratic, and quadratic base of square root models of linear regression, and it was chosen as a selection criterion of the more adequated models to the magnitude and significance of the coeficient of determination. The equations were adjusted by the means of the observed values to each determination.

\section{RESULTS AND DISCUTION}

\section{Grain yield}

The average grain yield of wheat cultivars increased significantly with a reduction of the soil $\mathrm{Al}$ saturation (Table 1). With the neutralization of exchangeable $\mathrm{Al}, 0 \%$ de aluminum saturation, the average yield of the evaluated cultivars were superior in 48,29 , and $16 \%$ to the yields obtained with 45,30 , and $15 \% \mathrm{Al}$ saturations, respectively.

Table 1 - Grain yield of wheat cultivars, in $\mathrm{kg} \cdot \mathrm{ha}^{-1}$, in different exchangeable Al soil saturation, in $\%$.

\begin{tabular}{lccccc}
\hline & \multicolumn{5}{c}{ Aluminum saturation (\%) } \\
\cline { 2 - 5 } Genotypes & 0 & 15 & 30 & 45 & Mean \\
\hline Trigo BR 23 & $2928 \mathrm{~A}$ & $2773 \mathrm{~B}$ & $2511 \mathrm{~B}$ & $2262 \mathrm{C}$ & $2619 \mathrm{~B}$ \\
IAPAR 29 & $3411 \mathrm{~A}$ & $2884 \mathrm{~B}$ & $2311 \mathrm{~B}$ & $1431 \mathrm{D}$ & $2510 \mathrm{~B}$ \\
IAPAR 60 & $3505 \mathrm{~A}$ & $3219 \mathrm{~A}$ & $2886 \mathrm{~A}$ & $2564 \mathrm{~B}$ & $3043 \mathrm{~A}$ \\
OCEPAR 16 & $3391 \mathrm{~A}$ & $2518 \mathrm{~B}$ & $2254 \mathrm{~B}$ & $2233 \mathrm{C}$ & $2599 \mathrm{~B}$ \\
Trigo BR 35 & $3505 \mathrm{~A}$ & $3367 \mathrm{~A}$ & $3225 \mathrm{~A}$ & $3023 \mathrm{~A}$ & $3280 \mathrm{~A}$ \\
IAPAR 6 & $3286 \mathrm{~A}$ & $2836 \mathrm{~B}$ & $2813 \mathrm{~B}$ & $2297 \mathrm{C}$ & $2808 \mathrm{~B}$ \\
IAPAR 53 & $3384 \mathrm{~A}$ & $3252 \mathrm{~A}$ & $2918 \mathrm{~A}$ & $2503 \mathrm{~B}$ & $3014 \mathrm{~A}$ \\
Trigo BR 18 & $3420 \mathrm{~A}$ & $2843 \mathrm{~B}$ & $2454 \mathrm{~B}$ & $2291 \mathrm{C}$ & $2752 \mathrm{~B}$ \\
IAC 5-Maringá & $3444 \mathrm{~A}$ & $3179 \mathrm{~A}$ & $3116 \mathrm{~A}$ & $2845 \mathrm{~A}$ & $3146 \mathrm{~A}$ \\
Anahuac & $3308 \mathrm{~A}$ & $2161 \mathrm{~B}$ & $1521 \mathrm{C}$ & $1189 \mathrm{D}$ & $2045 \mathrm{C}$ \\
\hline MEAN & $3358 \mathrm{a}$ & $2903 \mathrm{~b}$ & $2601 \mathrm{c}$ & $2264 \mathrm{~d}$ & 2782 \\
$F^{\mathrm{b}}$ & 0.44 & $3.72 * *$ & $4.64 * *$ & $9.40^{* *}$ & $12.68^{* *}$ \\
C.V. (\%) & 12.97 & 11.47 & 15.56 & 14.19 & 14.04 \\
\hline
\end{tabular}

${ }^{a}$ Means followed by the same capital letters, in the columns, and lower case letters, in the row, do not differ significantly among themselves by the Scott-Knott test at the 5\% probability.

${ }^{\mathrm{b}}$ Significative to a $1 \%(* *)$ probability level. 
Table 2 - Grain yield components, number of heads. $\mathrm{m}^{-2}$, number of kernels per head, and thousand kernel weight of wheat cultivars in different soil exchangeable Al saturation.

\begin{tabular}{|c|c|c|c|c|c|}
\hline \multirow[b]{2}{*}{ Genotypes } & \multicolumn{4}{|c|}{ Aluminum saturation $(\%)^{\mathrm{a}}$} & \multirow[b]{2}{*}{ Mean } \\
\hline & 0 & 15 & 30 & 45 & \\
\hline & \multicolumn{5}{|c|}{ Number of heads. ${ }^{-2}$} \\
\hline Trigo BR 23 & 435.0 & 416.7 & 402.5 & 371.7 & $406.4 \mathrm{~A}$ \\
\hline IAPAR 29 & 371.7 & 308.3 & 306.7 & 253.3 & $310.0 \mathrm{C}$ \\
\hline IAPAR 60 & 445.8 & 441.7 & 389.2 & 420.0 & $424.2 \mathrm{~A}$ \\
\hline OCEPAR 16 & 336.7 & 332.5 & 300.8 & 298.3 & $317.1 \mathrm{C}$ \\
\hline Trigo BR 35 & 429.2 & 413.3 & 417.5 & 447.5 & $426.9 \mathrm{~A}$ \\
\hline IAPAR 6 & 451.7 & 408.3 & 391.7 & 362.5 & $403.5 \mathrm{~A}$ \\
\hline IAPAR 53 & 465.0 & 481.7 & 450.8 & 380.0 & $444.3 \mathrm{~A}$ \\
\hline Trigo BR 18 & 441.7 & 431.7 & 395.0 & 383.3 & $412.9 \mathrm{~A}$ \\
\hline IAC 5-Maringá & 402.5 & 364.2 & 353.3 & 373.3 & $373.3 \mathrm{~B}$ \\
\hline Anahuac & 385.8 & 373.3 & 301.7 & 338.3 & $348.8 \mathrm{~B}$ \\
\hline MEAN & $416.5 \mathrm{a}$ & $397.2 \mathrm{a}$ & $370.9 \mathrm{~b}$ & $362.8 \mathrm{~b}$ & 386.9 \\
\hline $\mathrm{F}^{\mathrm{b}}$ & $2.27^{\mathrm{ns}}$ & $5.28^{* *}$ & $3.73 * *$ & $4.53 * *$ & $12.86^{* *}$ \\
\hline C.V. $(\%)$ & 11.31 & 9.96 & 12.76 & 12.49 & 11.34 \\
\hline
\end{tabular}

Number of kernels per head

$\begin{array}{lc}\text { Trigo BR 23 } & 20.0 \\ \text { IAPAR 29 } & 28.5 \\ \text { IAPAR 60 } & 23.0 \\ \text { OCEPAR 16 } & 27.4 \\ \text { Trigo BR 35 } & 24.7 \\ \text { IAPAR 6 } & 22.4 \\ \text { IAPAR 53 } & 19.9 \\ \text { Trigo BR 18 } & 20.6 \\ \text { IAC 5 } & 25.7 \\ \text { Anahuac } & 23.5 \\ \text { MEAN } & 23.6 \text { a } \\ \mathrm{F}^{\mathrm{b}} & 2.72 * \\ \text { C.V. (\%) } & 13.42\end{array}$

19.8

28.7

21.1

20.8

23.5

21.0

17.2

16.5

24.7

15.7

20.9 b

$7.95^{* *}$

11.71

18.1
24.4
22.7
19.8
23.8
22.8
16.6
15.6
25.3
13.5
$20.2 \mathrm{~b}$
$4.28 * *$
17.04

Thousand kernel weight (g)

34.0
32.6
34.9
36.8
35.1
33.0
39.3
40.2
35.5
36.9
35.8 a
$9.64 * *$
3.89

34.4
31.0
33.2
37.2
33.6
31.5
39.3
39.9
34.9
37.4
$35.2 \mathrm{a}$
$8.68^{* *}$
8.68

$34.0 \mathrm{C}$

${ }^{\mathrm{a}}$ Means followed by the same capital letters, in the columns, and lower case letters, in the row, do not differ significantly among themselves by the Scott-Knott test at the $5 \%$ probability.

${ }^{\mathrm{b}}$ Significative to a $1 \%(* *)$ and $5 \%(*)$ probability level. No significative (ns).

This means that liming was a necessary practice in the management of acid soils for wheat production. Among tested genotypes 'Anahuac' was the least productive genotype, confirming its non adaptation to the acidity conditions (Camargo and Oliveira, 1981; Baier et al., 1995). The most tolerant 
genotypes based on average yield across Al saturation were: 'Trigo BR 35', 'IAC 5-Maringá', 'IAPAR 60', and 'IAPAR 53' (Table1).

In the absence of toxic $\mathrm{Al}$ in the soil, there were no yield differences among wheat genotypes. At the other levels of Al saturation, significative differences among cultivars were observed, and the differences were higher with the increased level of $\mathrm{Al}$ in the soil. This fact indicated that productive genotypes had their yields reduced with the elevation of the element in the soil, and demonstrated variability for aluminum tolerance among the evaluated wheat cultivars.

\section{Yield components}

No significant interaction between cultivars and $\mathrm{Al}$ saturation for the evaluated yield components were observed. On average the reduction of soil Al saturation promoted an increase on the number of heads $\mathrm{m}^{-2}$ (NHM) and the number of kernels per head $(\mathrm{NKH})$, with no alteration on the thousand kernel weight (TKW) (Table 2). The increase in the observed grain yield (Table 1) with the reduction and neutralization of exchangeable $\mathrm{Al}$ was associated with an increase in the two first yield components.
Among the evaluated cultivars, 'Anahuac' was the least productive in the aluminum presence, showing a reduced number of kernels per head (NKH) in the presence of higher levels of toxic Al. The higher grain yield of 'Trigo BR 35', 'IAC 5-Maringá, and 'IAPAR $60^{\prime}$ was due to the association of high values of NHM and NKH, while 'IAPAR 53' was more productive due to increased TKW and elevated NHM. In the group of intermediate grain yield genotypes, 'IAPAR 6' and 'Trigo BR 23' presented high NHM, but had limited TKW and/or reduced NHM. 'Trigo BR 18' had yield reduced by low NKH, while 'OCEPAR 16' and 'IAPAR 29' had their potential reduced by low NHM. (Tables 1 and 2).

The grain yield of the evaluated wheat cultivars had a negative correlation with saturation of exchangeable soil $\mathrm{Al}$ and positive with NHM and $\mathrm{NKH}$, while TKW did not present significative correlation with the yield of grains. The correlation analysis reinforced that the presence of soil exchageable $\mathrm{Al}$ reduced the grain yield through a reduction of NHM and NKH. The negative correlation between NKH and TKW indicated a competition in the formation of these two yield components and would justify the absence of interference of TKW in the wheat grain yield (Table 3).

Table 3 - Correlation matrix between grain yield (GY), exchangeable Al saturation (ALSAT), number of heads. $\mathrm{m}^{-2}$ (NHM), number of kernels per head (NKH), and thousand kernel weight (TKW), of evaluated wheat cultivars.

\begin{tabular}{|c|c|c|c|c|}
\hline Variables $^{\mathrm{a}}$ & ALSAT & NHM & $\mathrm{NKH}$ & TKW \\
\hline GY & -0.59 & 0.66 & 0.65 & -0.10 \\
\hline & 0.00 & 0.00 & 0.00 & 0.27 \\
\hline ALSAT & ------- & -0.32 & -0.44 & 0.08 \\
\hline & & 0.05 & 0.00 & 0.39 \\
\hline NHM & ------- & ------- & $\begin{array}{r}-0.07 \\
0.45\end{array}$ & $\begin{array}{l}0.11 \\
0.23\end{array}$ \\
\hline NKH & ------- & ------- & ------ & $\begin{array}{r}-0.55 \\
0.000\end{array}$ \\
\hline
\end{tabular}

${ }^{a}$ For each pair of variables, the first number indicates the correlation coeficient (r), and the value below, the correlation probability estimated by the Student $t$ test.

Considering the average of evaluated parameters, which significantly affected grain yield, a mathematical model was calculated to estimate wheat grain yield (GY), in kg.ha ${ }^{-1}$ in function of the yield components NHM, NKH, and the soil Al saturation (ALSAT) in \%.

$$
\mathrm{GY}=4.57 \mathrm{NHM}+63.00 \mathrm{NKH}-11.81 \text { ALSAT }
$$

$$
\left(\mathrm{R}^{2}=0.992 * *\right)
$$

\section{Aluminum tolerance of wheat genotipes}

Considering the evidence of variability, the wheat genotypes were characterized for $\mathrm{Al}$ tolerance through an adjustment of regression equation between the GY of each cultivar and the ALSAT 
(Table 4). From the equations, an estimation of GY at $45 \%$ Al saturation for each genotype was calculated.

Table 4 - Adjusted regression equations between grain yield in kg.ha-1, as dependent variable (Y), and soil $\mathrm{Al}$ saturation in \%, as dependent variable $(\mathrm{X})$.

\begin{tabular}{lcc}
\hline Genotypes & Regression equation & Coeficient of determination $\left(\mathrm{R}^{2}\right)^{\mathrm{a}}$ \\
\hline Trigo BR 23 & $\mathrm{Y}=2957.50-15.07 \mathrm{X}$ & $0.989^{* *}$ \\
IAPAR 29 & $\mathrm{Y}=3486.00-43.40 \mathrm{X}$ & $0.984^{* *}$ \\
IAPAR 60 & $\mathrm{Y}=3516.90-21.04 \mathrm{X}$ & $0.999^{* *}$ \\
OCEPAR 16 & $\mathrm{Y}=3395.13-311.58 \mathrm{X}^{1 / 2}+20.22 \mathrm{X}$ & $0.991^{*}$ \\
Trigo BR 35 & $\mathrm{Y}=3518.20-10.59 \mathrm{X}$ & $0.991^{* *}$ \\
IAPAR 6 & $\mathrm{Y}=3256.50-19.93 \mathrm{X}$ & $0.912^{*}$ \\
IAPAR 53 & $\mathrm{Y}=3460.80-19.85 \mathrm{X}$ & $0.955^{*}$ \\
Trigo BR 18 & $\ln \mathrm{Y}=8.11-0.009 \mathrm{X}$ & $0.963^{*}$ \\
IAC 5-Maringá & $\mathrm{Y}=3425.00-12.40 \mathrm{X}$ & $0.952^{*}$ \\
Anahuac & $\ln \mathrm{Y}=8.06-0.022 \mathrm{X}$ & $0.986^{* *}$ \\
\hline
\end{tabular}

${ }^{\mathrm{a}}$ Significative to the $5 \%(*)$, and $1 \%\left({ }^{* *}\right)$ probability levels by the t-test.

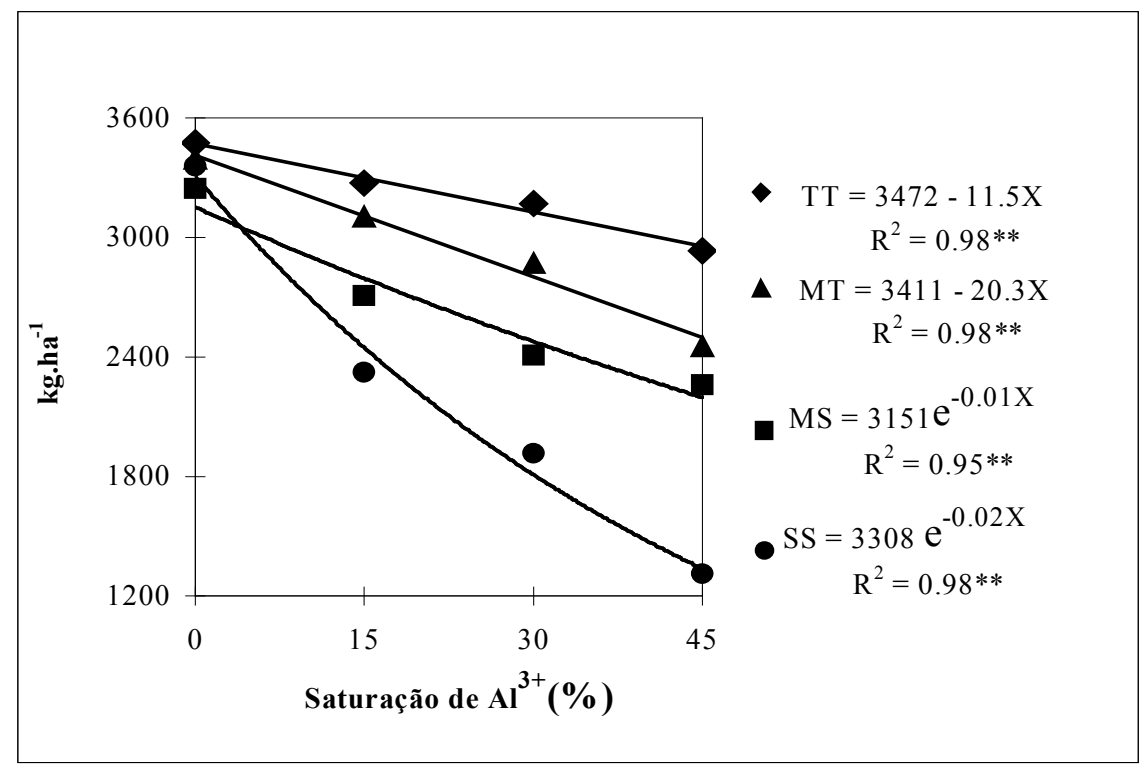

Figure 1 - Effect of exchangeable soil $\mathrm{Al}$ on the grain yield of wheat, by groups of $\mathrm{Al}$ reaction, sensitive (SS), moderately sensitive (MS), moderately tolerant (MT), and tolerant (TT).

An index of toxic Al tolerance, for each genotype, through the relation between estimated yield by the equation of $45 \% \mathrm{Al}$ saturation and the average yield of the 10 cultivars tested in this level of saturation was established.

These index were distributed in four frequency classes, corresponding to sensitive, moderately sensitive, moderately tolerant, and tolerant cultivars. The cultivars 'Anahuac' and 'IAPAR 29' were considered sensitive having grain yield at least
$20 \%$ lower than the mean of 10 wheat cultivars evaluated in the $45 \% \mathrm{Al}$ saturation. The cultivars 'OCEPAR 16', 'Trigo BR 18', and 'Trigo BR 23' were moderately sensitive and their yield means were up to $20 \%$ lower to the cultivar group mean, when evaluated in the highest level of exchangeable $\mathrm{Al}$ in the soil. The moderately tolerant cultivars 'IAPAR 6', 'IAPAR 53', and 'IAPAR 60' yielded up to $20 \%$ above the mean, while the considered tolerant 'IAC 5-Maringá', and 'Trigo BR 35' yielded 
between $21 \%$ to $40 \%$ above the mean of the 10 evaluated cultivars in the $45 \% \mathrm{Al}$ saturation. The used criteria to separate wheat genotypes into different tolerance classes allowed the effective placement of tested cultivars (Camargo and Oliveira, 1981; Baier et al.,1995).

To the means of each tolerance group defined previuosly regression equations were adjusted (Figure 1). In the soil exchangeable Al tolerance of $45 \%$, the genotypes considered tolerant such as 'IAC 5-Maringá', and 'Trigo BR 35', presented mean grain yield equivalent to the estimated in the $23.5 \%$ Al saturation for the moderately tolerant group, to $9.5 \%$ for the moderately sensitive, and $7.8 \%$ for the sensitive genotypes (Figure 1).

It could be concluded that the use of $\mathrm{Al}$ tolerant cultivars was a fundamental component for the successful cultivation of wheat in acid soils.

\section{CONCLUSIONS}

The grain yield of wheat was reduced by the elevation of soil Al saturation. Differences among evaluated genotypes indicated the existence of genetic variability for $\mathrm{Al}$ tolerance. The yield components, number of heads. $\mathrm{m}^{-2}$ and number of kernels per head, were negatively correlated with soil Al saturation and positively with grain yield. The same did not happen with thousand kernel weight. The wheat genotypes had a different response to the toxic soil Al. In the sensitive group were Anahuac and IAPAR 29. OCEPAR 16, Trigo BR 18, and Trigo BR 23 were moderately sensitive; IAPAR 6, IAPAR 53, and IAPAR 60 were moderately tolerant; while IAC 5-Maringá and Trigo BR 35 were tolerant.

\section{RESUMO}

Dez cultivares de trigo foram submetidos à saturações de alumínio (SATAL) de 0, 15, 30 e $45 \%$, para avaliar a tolerância desses materiais à toxidez de alumínio. O experimento foi conduzido em Londrina, PR, em 1994, usando microparcelas, com material de solo de um Latossolo Roxo álico (Haplorthox típico), com $65 \%$ de saturação de alumínio, corrigido com calcário dolomítico, para se obter as saturações acima mencionadas. O delineamento experimental foi em blocos ao acaso com distribuição em parcelas subdivididas. As diferenças entre cultivares de trigo foram caracterizadas pela produção de grãos (PGT) e os componentes de rendimento: número de espigas $\mathrm{m}^{-2}$ (NEM), número de grãos espiga ${ }^{-1}$ (NGE) e massa de mil grãos (MMG). Observou-se diferença na produção de grãos e nos componentes de rendimento entre os cultivares testados. Aumento na SATAL diminuiu a PGT, o NEM e o NGE; não se observou alteração na MMG.

Os cultivares de trigo reagiram diferentemente em relação à toxidez de alumínio. 'Anahuac' e 'IAPAR $29^{\prime}$ foram os materiais mais sensíveis. Os cultivares 'OCEPAR 16', 'Trigo BR 18' e 'Trigo BR 23 ' foram considerados moderadamente sensíveis, enquanto o 'IAPAR 6', 'IAPAR 53' e 'IAPAR 60' apresentaram-se como moderadamente tolerantes ao alumínio. O 'IAC 5-Maringá' e o 'Trigo BR 35' foram caracterizadas como cultivares tolerantes à presença de alumínio tóxico no solo.

\section{REFERENCES}

Baier, A. C.; Somers, D. and Gustafson, J. (1995), Aluminum tolerance in wheat: correlating hydroponic evaluations with field and soil performances. Plant Breeding, 114, 291-294.

Baligar, V. C. and Fageria, N. K. (1996), Nutrient use efficiency in acid soils: nutrient manegement and plant use efficiency. In: Moniz A.C. et al. (ed.). PlantSoil Interactions at Low $p H$. Belo Horizonte. Proceedins... Viçosa/Campinas, Brazilian Soil Science Society, 1997. pp.75-95.

Camargo, C. E. O.; Ramos, L. C. S.; Ferreira Filho, A. W. P.; Felício, J. C.; Pettinelli Júnior, A.; Castro, J. L. and Yohoo, E. Y. (1999), Linhagens diplóide de trigo: produção de grãos, características agronômicas e tolerância à toxicidade de alumínio Bragantia, 58 : (2), 235-46.

Caramori, P. H.; Oliveira, D. and Farias, R. T. (1991), Freqüência de ocorrência de períodos com deficiência hídrica (veranicos) no Estado do Paraná. Boletim técnico IAPAR, (36), 1-40.

Carver, B. F. and Ownby Y. J. D. (1995), Acid soil tolerance in wheat. Adv. Agron., 54, 117-73.

Foy, C. D. and Brower, J. C. (1964), Toxic factors in acid soils II Diferencial aluminum tolerance of plants species. Soil Sci. Soc. Am. Proc., 28, 27-32.

IAPAR (2000), Informações técnicas para a cultura do trigo no Paraná. IAPAR Circular, 109, 1-152.

Muzilli, O.; Santos, D.; Palhano, J. B.; Manetti Filho, J.; Lantmann, A. F.; Garcia, A. and Cataneo, A. (1978), 
Tolerância de cultivares de soja e de trigo a acidez do solo. R. bras. Ci. Solo, 2, 34-40.

Okuyama, L. A. and Costa, A. (1990), Avaliação de genótipos de trigo para resistência à seca em solo com saturação de alumínio. Informe da Pesquisa IAPAR, 94, 37-41.

Quaggio, J. A. (2000), Acidez e Calagem em Solos Tropicais. Campinas : Instituto Agronômico. $111 \mathrm{pp}$.

Riede, C. R. and Campos, L. A. C. (1988), Development of wheat cultivars with higher yield and adaptation to different agroclimatic conditions of Paraná. In: Kohli, M. M.and Rajaram, S. (eds.). Wheat breeding for acid soils: Review of Brazilian/CIMMYT collaboration, 1974-1986. CIMMYT, México. pp. 26-38.

Uexküll, H. R. von and Mutert, E. (1995), Global extent, development and economic impact of acid soils. Plant and Soil, 17 : (1), 5-19.

Received: May 16, 2001;

Revised: July 27, 2001; Accepted: January 18, 2002. 


\title{
PÁGINA
}

\author{
EM
}

BRANCO 